\title{
IN SEARCH OF THE KYOTO MODERN
}

\author{
John Breen, Maruyama Hiroshi, Takagi Hiroshi
}

80

\section{MODERN KYOTO RESEARCH}

JAPAN IS OFTEN cited as the one Asian nation to have modernized both successfully and swiftly in the nineteenth century. Modernization in this context refers to industrialization, and the rapid economic growth it brings. This narrative is dominant, for example, in the many commemorative events, lectures and exhibitions that are taking place at the time of writing to mark the 150th anniversary of the Meiji Restoration. Typically, sponsors, lecturers and curators locate the Meiji Restoration as the starting point of Japan's modernization process, before narrating tales of modern Japan's success. The somber historical truth is that the Meiji Restoration left in its wake political and socio-economic chaos.

The city of Kyoto, the spatial focus of this book, suffered grievous damage in the aftermath of the Meiji Restoration of 1868 , and yet in the midst of adversity it underwent a dramatic transformation. After the emperor and his court uprooted and left for Edo (Tokyo) in 1869, even the Imperial Palace fell into disrepair. But then the city began a process of rapid modernization; it modernized faster, in fact, than any city in the land. At the same time, it set out to demonstrate that its thousandyear history as the country's imperial center was a legacy vital to the modern nation. It became a vibrant, modern "ancient capital." Such was the trajectory of Meiji-period Kyoto's 
renaissance. The trajectory was also one of sustained resilience, a term that implies a system's capacity to function even as it is subject to environmental buffeting. There is no doubt that Kyoto was seriously buffeted, and no doubt that it proved resilient. Kyoto not only survived; it thrived in modern Japan. This book sets out to study the nature of Kyoto's modern experience.

Kyoto's thousand-year history began in 794 when it was founded as the imperial capital Heian. The city became the politi$\mathrm{cal}$, financial and cultural center of Japan. And so it remained for eight hundred years, until the creation of the Tokugawa shogunate in Edo in 1600. Japan's political center shifted east now to Edo, and the financial hub relocated west to Osaka, following the development of east-west water routes in the early seventeenth century. Kyoto meanwhile retained its status as Japan's cultural center, on account of the imperial presence. This separating-out of the three different functions, political, financial and cultural, fulfilled in an earlier age by Kyoto alone resulted in the birth of three thriving cities. If it also represented the end of Kyoto's overarching influence in Japanese life, the city's ultimate decline came with the Meiji Restoration, and the imperial court's relocation to Tokyo. What remained behind in Kyoto was, of course, a rich cultural heritage, but even this was accorded little value - at least initially - by modern Japan's imperial government.

What then was the dynamic of Kyoto's renaissance, and what the substance of its resilience? During the period of immediate post-Restoration decline, Kyoto made multiple attempts to become a modern, industrial city. As early as 1871, the city hosted the first of many Kyoto exhibitions; they became thereafter an annual event. Exhibitions were integral to the city strategy of attracting visitors - not only Japanese but foreign visitors now, too. The city sponsored the construction of hotels for tourists, and the publication of city guides. These included the pioneering English-language Guide to the Celebrated Places in Kyoto and the Surrounding Places, which appeared as early as 1873 . Miyako no sakigake (The Capital as Forerunner) published in 1883, was the 
first guide to the city's burgeoning commerce and industry as it underwent regeneration. In 1895, the city published the Heian tsüshi (A Narrative History of Heian) which was not only the first official history of Kyoto, but one of the first city histories in modern Japan. Kyōto meishō annai ki (Guide to Famous City Sites), which went through three printings in three months and sold 300,000 copies, was published in the same year; so too was the substantial English language Official Guidebook to Kyoto and Allied Prefectures. These publishing initiatives coincided with Kyoto's hosting of the Fourth National Industrial Exhibition in 1895, and the celebrations for the Eleventh-Centenary of the city's founding.

After the Restoration, Kyoto set out on a path to promote industry and commerce, and redefine itself as a new and modern industrial city. It scored some major successes. Kyoto had Japan's first state school, its first public library, its first hydroelectric power station, and its first street cars. Japan's first town hall, its first film projection, and its first symphony orchestra were all to be found in Kyoto. At the same time, though, Kyoto made much of the fact that its history was inextricably linked to the imperial court. The city exploited its imperial legacy to claim a unique place in the life of modern Japan and become a modern functioning "ancient capital." If Kyoto demonstrated now a voracious appetite for change, it was sustained by a deep-flowing tradition of continuous creativity. It was the accumulation of knowledge and the consolidation of traditional skills over generations that propelled Kyoto into the modern era. The city's traditional Aoi and Gion Festivals, engendered a multitude of tangible and intangible industries and performing arts, which modern Kyoto inherited. The city's many shrines and temples, survived as vigorous patrons of the arts, and as cultivators of some of the country's finest gardens. This is not withstanding the fact that they were hit hard by the early Meiji government's religious policies. Early modern industries grew up around the imperial court and religious institutions, and quarters were established in the city where artisans lived and worked, refining their skills often under 
the most difficult conditions. That traditional skills survived throughout the early modern period and into the modern period was owing not least to the fact that Kyoto was a nonmilitary city. Unlike all the other greater cities that flourished from the early modern period, its center was not a castle, but the imperial palace.

The eleventh-centenary of the city's founding merits a special place in any account of Kyoto's modern history. The event celebrated the illustrious history of a great city, of course, but it was as much a celebration of modern Japan's imperial character. This was an event of national import, and it served to re-locate Kyoto at the very center of Japanese culture. EleventhCentenary celebrations involved a re-imagining of Kyoto's city space, with the development of land in the Okazaki district east of the Kamo River that runs through central Kyoto. This was the location for the brand-new Heian Shrine, an extraordinary structure built in the very image of the Heian period imperial court. The spirit of Emperor Kanmu, the city's founder, was venerated therein; in later years, the spirit of Emperor Kōmei, the last emperor to reign from the Kyoto palace, was added to the shrine's pantheon. The shrine now became the focus for a new city festival, the so-called Jidai (or Period) Festival. It was a history pageant, which recreated heroic and historic moments from the city's imperial past. It was typical of the city's approach to the modern age that it hosted Japan's Fourth National Industrial Exhibition on the same site and at the same time as the eleventh-centenary foundations. The first three such exhibitions, in 1877, 1881, and 1890, had all been held in Ueno Park in the capital Tokyo. Kyoto, the city of imperial tradition, was now staking its claim to be a truly modern city alongside Tokyo.

In terms of city planning, however, Kyoto lagged far behind Tokyo, which as the nation's capital was the first to undergo the modern treatment. Tokyo's unique position as modern imperial capital was consolidated by the Home Ministry with a city planning ordinance in 1888 . The environs of the new Tokyo imperial palace and parts of downtown Tokyo were renovated 
to bring them into line with the major urban centers of Europe and the United States. Old roads were broadened and new roads constructed; rivers, bridges and parks were all subject to renovation. But it was not for another thirty years, namely in 1918, that a similar ordinance was applied to Kyoto. But Kyoto's unique and vital place as the ancient capital of modern imperial Japan - indeed, one of the great cities of the world was established long before 1918.

\section{TOWARDS A MODERN HISTORY OF KYOTO}

The present volume is the first in English dedicated exclusively to exploring Kyoto's modern transformation. ${ }^{*}$ It opens with the section Emperor, Rites, and Religion, the first chapter of which is Takagi Hiroshi's "The Emperor System and Kyoto: Images of the Ancient Capital." Takagi argues that the court's connection with local society was severed with the emperor's departure in 1869. He goes on to explore the process by which, in the 1880 s, Kyoto's character as ancient capital and home to a unique imperial cult-ure was consciously constructed to render it distinct from, but by no means inferior to, the capital Tokyo. This was a process which eventually bore fruit in the twentieth century with the performance in Kyoto of the enthronement rites for the Taisho and Showa emperors. In "Performing History: Festivals and Pageants in the Making of Modern Kyoto," John Breen's focus falls on Kyoto's three great festivals, the modern Jidai Festival and the much older Aoi and Gion Festivals. Breen traces the trajectories of these festivals in the nineteenth and early twentieth centuries, and argues that they - along with the imperial rites of enthronement - served a vital strategic function in the flourishing of modern Kyoto. In his chapter "Buddhism and Society in Modern Kyoto," Tanigawa Yutaka is concerned with Buddhism as it re-energized itself during the adversity of the Restoration

* After the completion of the manuscript for this volume, Alice Tseng published Modern Kyoto: Building for Ceremony and Commemoration, 1868-1940, University of Hawaii Press, 2018. For other work by Alice Tseng on modern Kyoto, see below p.xxii 
period. Tanigawa explores the dynamics of Buddhism's modern transformation as it confronted the Meiji state's anti-Buddhism, and the confiscation of vast tracts of Buddhist land. In the end, he shows that it was Kyoto's rich and resilient religious culture that made the city indispensable to the modern state.

The second section Urban Spaces, Local Communities, and Cityscapes comprises chapters by Nakagawa Osamu, Kobayashi Takehiro and Maruyama Hiroshi. Nakagawa's "Embodying History: The Modern Reorganization of Kyoto's Urban Space" explores Kyoto's regeneration as it engaged with new approaches to urban space. He focuses on the so-called "three major construction projects" (sandai jigyō): the construction of a second Lake Biwa Canal, the sewage system as well as the broadening of streets and laying of street-car tracks. He finds that the key to success was the role played by Kyoto's unique community organizations. In his chapter "The Eleventh-Centenary of the Founding of Heian and the Construction of Heian Shrine," Kobayashi shows how the eleventh-centenary celebrations, launched as an attempt by Kyoto entrepreneurs to promote Kyoto, developed into a national commemoration. Government ministers and powerful bureaucrats became involved, as plans for celebrations merged with Kyoto's bid to host the Fourth National Industrial Exhibition. Finally, Maruyama in his chapter "Kyoto's Forest Policy: Scenic Beauty and Urban Fringe Forests" points up the wealth of natural beauty which Kyoto inherited from the forests belonging to the city's shrines and temples on the outskirts of the city. He then explores the process by which scenic beauty came to be protected through the forest protection system (hoanrin seido) and the scenic area system (füchi chiku seido). The forests of temples and shrines stand to this day as a protective buffer for classical Kyoto's historic skyline.

The final section Industry, Arts, and Craftsmanship begins with a chapter by Takaku Reinosuke, "Transforming Early Meiji Kyoto: Towards an Industrial City." Takaku examines Kyoto's engagement with industrialization and city regeneration, especially in regard to the construction of the Lake Biwa 
Canal engineering works. He plots the ups and the downs of the project, and argues that the construction of the canal itself, and the resulting switch to hydraulic power, left a lasting legacy on the Kyoto cityscape, and had a major impact on the Kyoto's modernization. Kuniga Yumiko's chapter, "Nihonga in Kyoto at the Dawn of the Modern Era" provides a critical overview of Nihonga painting in the modern era, arguing that this traditional form of Japanese art, originally developed for use in interior design, provided visual inspiration for export wares, which then contributed to government policies intended to promote industry. She traces the historical dynamic forward to the establishment of the concept of fine arts (bijutsu), and Japanese artists' struggles to make sense of the new age. In his chapter "Trends in Modern Kyō-yaki Pottery: on Design in the Meiji Period," Yoshii Takao shows how potters, the artisans of Kyoto's great traditional industry, set out in search of design innovations to bring ceramics into the modern age. They obtained information from international expositions, and directly from European potters, in order to promote exports and develop traditional designs for an international market. Yoshii finds that the rich variety of twenty-first century Kyoto ceramics is rooted in innovations in the latter half of the Meiji period.

\section{ANGLOPHONE RESEARCH AND THE ABSENT MODERN}

The present volume may be the first volume in English dedicated solely to Kyoto's modern experience, but Kyoto history has before now attracted the attention of many fine Anglophone historians. This section offers a survey of some of the most notable studies of the city. This, after all, is the intellectual context out of which the present volume emerges. The first-ever history of Kyoto in the English language was written by Richard Ponsonby-Fane in 1931. Kyoto: its history and vicissitudes since its foundation in 792 to 1868 was a compilation of four long articles on Kyoto, which the author had previously penned for the Japan Society of London. Ponsonby-Fane, who took up 
residence in the city in 1924, drew largely for his insights on the afore-mentioned Heian tsüshi, the first Japanese history of Kyoto. The year after Ponsonby-Fane published his Kyoto, he moved to a house near the Lower Kamo Shrine, and there he resided until his death in 1937. It is said he was "outrageously old-fashioned, and disliked everything modern." It is ironical then that the city that he loved with a passion was one of the first to acquire all the trappings of urban modernity.

Ponsonby-Fane ends Kyoto at the Restoration of 1868, and he has very little to say about the modern period. Each of his chapters offers "comprehensive accounts" of the palaces, temples, shrines, gardens of the city in the Heian period (7491229), the Middle Ages (1221-1582), the Momoyama period (1582-1615) and the Edo or Tokugawa period (1615-1869). ${ }^{2}$ Only occasionally does he follow the fortunes of these structures through to Meiji and beyond. This is the case, for example, with his discussion of the palace buildings abandoned by the emperor and his court in 1869. The several new shrines constructed in modern Kyoto to commemorate the great men of the city's past - especially the Heian Shrine - fascinated him. But he has nothing more to say, good or bad, about the dramatic transformation that Kyoto underwent after the Restoration of 1868.

Alex Kerr's Another Kyoto is, at the time of writing, the latest book-length study of historical Kyoto. ${ }^{3}$ Kerr shares with Ponsonby-Fane a distaste for the Kyoto modern. He delights only in Kyoto's pre-modern past. Kerr knows the city as well as any foreigner since Ponsonby-Fane, and brings his insights to bear in a most novel way. The city's gates, walls and floors are the spatial markers he deploys to unlock Kyoto's historical riches. The temple-like gate at the Chion'in fascinates him, as do Tōfukuji's door-less gate, thatched gates like those at Hōnen'in, and of course the ubiquitous torii or shrine gates, most con-

\footnotetext{
Britton 1997.

Ponsonby-Fane 1931.

Kerr and Sokol 2016.
} 
spicuous in the "gate-themed landscape" of the Fushimi Inari Shrine. Kyoto does not want for walls, either: "cosmic walls" delimit the spaces of the typical Kyoto temple with its meditation halls, pagodas, and sutra repositories, with Myōshinji offering what Kerr calls the "full wall experience." Kerr reflects too on the floors of many of Kyoto's historical structures. The black glistening wooden floors at Jissō-in impress him, and when it comes to the historically much later tatami floor, the imperial palace's Tsune goten hall, the reception hall of Nijo Castle and, indeed, the Reikanji nunnery count among the city's finest.

For more conventional readings of Kyoto's past, Kerr points the reader to Gouverneur Mosher's Kyoto: A Contemplative Guide and John Dougill's Kyoto: A Cultural History. ${ }^{4}$ Mosher, it proves, has no more interest in modern Kyoto than Kerr or Ponsonby-Fane. For Mosher, Kyoto's history grinds to a halt on the eve of the Restoration. ${ }^{5}$ His method is to negotiate urban history through specific landmarks. So, for example, the Shūgakuin Imperial Villa in the northeast, the shogun's Nijo Castle in the west, and the nearby "fortified inn" known as Nijō jinya embody for him the city's Edo-period, but this is as far as he goes. He even advises readers to avoid the Heian Shrine on the grounds that it was a Meiji invention. He laments its utter lack of cultural interest. ${ }^{6}$ Dougill begs to differ, and unlike Mosher, he finds much to admire in the Heian Shrine, its structures, its gardens and festivals. He notes with admiration how in Meiji, "almost overnight, [Kyoto] transformed itself from a city of tradition into the country's leading modernizer." He underscores the point with an inventory of some of the Kyoto city "firsts" referred to above. ${ }^{7}$ Dougill reflects with due awe on the late-nineteenth century Lake Biwa Canal project, a pioneering feat of engineering that cut a path through the mountains from the lake into the city. As he notes, the channeled

\footnotetext{
Mosher 1964.

Plutschow 1992.

Mosher 1964, p. 22.

Dougill 2006, p. 198.
} 
water not only irrigated the city, it transformed it visually. The water drove Kyoto's innovative hydro-electric power station, which ran Kyoto's trams. All this Dougill admires, and his admiration for modern Kyoto makes his book the better by far of the two.

Mosher and Kerr have both written short, digestible city histories for the general reader, and make no claims for originality. But the last two decades or so have seen a succession of insightful Kyoto studies written in English by academics from multiple perspectives. Much of the best work has an intriguingly medieval bias. There is Mary Elizabeth Berry's masterful exploration of the convulsion of war and its impact on the imperial capital in the fifteenth and sixteenth centuries; ${ }^{8}$ Suzanne Gay has written on sake-brewing moneylenders and their place in the flourishing urban culture of late medieval Kyoto;' and Matthew McKelway has penned the definitive work on the genre of medieval Kyoto folding screens, known as rakuchū rakugai zu. ${ }^{10}$ Matthew Stavros' urban history of Kyoto deftly deploys textual, pictorial and archaeological sources to track the city's spatial evolution from the eighth through the seventeenth centuries. Stavros interestingly concludes his book by casting forward to Kyoto's modern experience. Modernity impacted profoundly on Kyoto's urban and architectural heritage, he observes, and "on balance, it enhanced Kyoto's cultural legacy." 11

Other studies have begun, albeit falteringly, to address Kyoto's modern concerns more directly. Tamara Hareven's The Silk Weavers of Kyoto is rooted firmly in postwar Japan, and she notes - albeit briefly - the transformation worked by the introduction into Meiji period silk-weaving of the jacquard and the power-loom. If history is not Hareven's forte, her book nonetheless offers a vivid perspective on weavers and work in modern Kyoto's Nishijin district, through insightful comparisons with Europe

\footnotetext{
Berry 1997.

9 Gay 2001.

10 McKelway 2006.

11 Stavros 2015, p.184.
} 
and the USA. ${ }^{12}$ City history is precisely the strength of the fine collection of essays assembled by Nicolas Fiévé and Paul Waley. ${ }^{13}$ Five of the fourteen chapters in Japanese Capitals in Historical Perspective tackle Kyoto, but curiously not one explores its Meiji period transformation. In narrating the development of Kyoto's Shimabara pleasure quarters, Fiévé does look ahead to the modern period, noting briefly how the construction of railways and roads led to Shimabara's loss of both status and custom. ${ }^{14}$ And the editors in their introduction refer tantalizingly to Kyoto's "major modernization scheme" that began with the construction of the Heian Shrine for the city's eleventh centenary. But that is about it. In its otherwise thoughtful conclusion on memory, power and place, Kyoto's Meiji experience does not merit a mention.

For all its historical insights, Japanese Capitals has fewer references to Meiji period Kyoto than does Christoph Brumann's Tradition, Democracy and the Townscape of Kyoto, which is not a history book at all. Brumann is an anthropologist with a sharp historical eye. His masterful study of postwar Kyoto explores the "social anatomy" of the city's countless conflicts over planning and building. With skill, he sketches the historical contexts for his observations on the ill-fated plan for a Pont des Arts style footbridge across the Kamo River; on the Gion Festival and the social structures sustaining it in the postwar; on what he calls Kyoto's "issue-oriented civic activism," and on the revival of traditional Kyoto residential architecture, the distinctive machiya. The book succeeds in its portrayal of post-war Kyoto citizens as they struggle to "bring the past into the future."

In brief, until very recently there has been a Meiji-shaped hole in English-language studies of historical Kyoto. This makes Kyoto: Visual Culture in the Early Edo and Meiji periods, a collection of essays edited by Morgan Pitelka and Alice Tseng, most

12 Hareven 2002.

13 Fiévé and Waley 2013. Nicolas Fiévé is also the editor of the magnificently produced Atlas historique de Kyoto, Editions de l'Amateur, 2008. This, too, has a distinct medieval bias.

14 Fiévé 2013, pp. 67-99. 
welcome. ${ }^{15}$ In their introduction, Pitelka and Tseng propose intriguing parallels between early Edo and early Meiji Kyoto. The Tokugawa regime set up its powerbase in the early seventeenth century in Edo, some $500 \mathrm{~km}$ east of Kyoto. In the wake of the 1868 Restoration, the emperor and his court vacated Kyoto for Edo, which duly became modern Japan's eastern capital of Tokyo. Both historical junctures dislocated Kyoto from the political center, prompting in its citizens, entrepreneurs and proprietors an anxiety of loss and a longing for stability and prosperity. The volatility of both junctures triggered in Kyoto city dwellers "an upswing" in cultural activity and production, resulting in a "constellation of fine, decorative and building arts" that distinguished and sustained the city. Four essays in the collection explore this dynamic as it shaped Meiji period Kyoto.

Alice Tseng cautions that the urban convulsion of early Meiji far exceeded that of early Edo, before exploring cultural revival in the construction of open public spaces. The city, bereft of emperor and court, imbued two sites anew with imperial associations: Kyoto Imperial Garden - a new type of urban space that vivifies the city's "perishing center" - and Okazaki Park - a hybrid space, at once imperial and democratic, historical and modern, religious and secular. The development of such spaces constituted nothing less than a modern remapping of the ancient capital. Yasuko Tsuchikane writes boldly of Buddhism in Meiji period Kyoto, arguing that it underwent a crisis graver than at any time since its arrival in Japan in the sixth century. Her concern is to track the restoration of Buddhist fortunes, and the strategic use of works of art in this endeavor. She sees as symbolic of Buddhism's post-persecution revival the early Meiji rebuilding, and the artistic decorating, of the Higashi Honganji Temple. Julia Sapin then focuses on the resurgence of Kyoto's textile industry, which for her is key to the city's modern economic development. Her interest is in textile production as a "site" where the naturalist painting style of classic Kyoto fused with modern artistic trends of a city-wide endeavor

15 Pitelka and Tseng 2016. 
to validate Kyoto's past. Toshio Watanabe, in his concluding chapter, then focuses on modern Kyoto's gardens. He is drawn to the Murin-an, a garden designed for statesman Yamagata Aritomo by Ogawa Jihei in the 1890s. He identifies its impact on other modern Kyoto gardens, like that of the Heian Shrine, before offering some provocative reflections on the modern reimagining of the famous Zen rock-garden at Ryōanji Temple. ${ }^{16}$

\section{RESEARCHING MODERN KYOTO: STRATEGIES AND SOURCES}

Kyoto's modernizing endeavor in the Meiji period resulted eventually in the national government recognizing Kyoto for its history and traditions. This explains the dominant premodern focus of Kyoto studies. The ancient Heian, medieval Muromachi and early modern Azuchi-Momoyama and Edo periods have received most of the academic attention. Indeed, academic historians of Japan to this day set great store by empirical research into ancient and mediaeval history. Research into modern and current history is a much more recent phenomenon.

A special feature of this volume, Kyoto's Renaissance, is that it makes the empirical case for a multifaceted modern Kyoto, drawing as it does on a vast array of historical materials from local society. It acknowledges the aspects of tradition that endured from the Heian period through the medieval period and beyond, even as it sheds light on Kyoto's modern renaissance after the Meiji Restoration. Kyoto was devastated in the fifteenth century Onin Wars and the great conflagration, caused by civil strife in 1864, but apart from some small-scale bombing in the Umamachi and Nishijin blocks of the city, Kyoto escaped the devastating bombing raids of the Asia-Pacific War. Kyoto was, in fact, the first choice for the detonation of the atomic bomb, but it was spared for political considerations, namely to ensure US hegemony in the post-war era. ${ }^{17}$ As a result, a wealth of historical documents

\footnotetext{
16 For a comprehensive overview of research on modern Kyoto in Japanese, see below.

17 Yoshida 2002.
} 
relating to premodern Kyoto - as well as to the modern period survive to this day. These include documents relating to various city neighborhood blocks $(c h \bar{o})$, documents held by shrines and temples, and documents relating to the administration of Kyoto City and Kyoto Prefecture.

The Kyoto Institute, Library and Archives, located in the city's Sakyō Ward, makes public archives easily accessible to the researcher. ${ }^{18}$ Inaugurated by Kyoto Prefectural Governor Ninagawa Torazō in 1963, this was the first administrative archive opened to the public anywhere in Japan. The Kyoto Institute houses over 15,000 administrative documents from Kyoto Prefecture, dating from the Meiji period through until 1946; the collection is designated an important cultural property. Kyoto and, indeed, the adjacent prefectures of Nara and Shiga today boast a wealth of official documents on politics, the economy, culture and religion dating back to Meiji. The nearby prefectures of Hyōgo and Ōsaka, by contrast, lost much in the extensive bombing. Of especial value to researchers working on modern Kyoto are the diaries of Kitagaki Kunimichi. Kitagaki, the Kyoto prefectural governor who oversaw the construction of the Lake Biwa Canal project, set the tone for Kyoto's enlightened prefectural administration in the first half of the Meiji period. ${ }^{19}$ The Kyoto Institute holds around 320,000 books, with a particular focus on reference materials relating to Kyoto. Included are early-modern publications, bound Japanese style, as well as more modern publications bound in the Western style. In addition, administrative documents from the city of Kyoto may be viewed at the Public Information Corner at Kyoto City Hall.

The Kyoto Institute houses, moreover, the largest collection of magazines published in the Kyoto municipal area, including the art magazine, Kyōto bijutsu kyökai zasshi (1892-1905) and

18 This archive, known in Japanese as Kyōto Furitsu Kyōtogaku Rekisaikan (Rekisaikan for short), opened in 2016. It stands on the site of, and replaces, the old Kyoto Prefectural Library and Archives (Kyōto Fu Sōgō Shiryōkan).

19 Kitagaki's diaries have been published as Jinkai Kenkyūkai ed., 2010. 
the education journal, Kyōto kyōiku (1883-1943). Newspapers too are an essential resource for the study of modern Kyoto, and the Kyoto Institute holds original copies of many of the newspapers published in the Kyoto municipal area, including the Kyoto shinbun and its precursor the Hinode shinbun, first published in 1885. Microfilm versions of these newspapers are also kept at the major universities in Kyoto. The Miyako kioku (or Municipal memory) online archive is an indispensable tool for researchers looking for historical sources in all periods of Kyoto history. It is accessible though the Kyoto Institute webpage. Books, journals and documents can all be searched online, and there are visual images there aplenty too. ${ }^{20}$ The Kyoto Institute also hosts the archives of the Tōji Temple (Kyōō Gokokuji), one of the most powerful in the land from the ancient period until modern times.

Another essential public archive is the Kyoto City Library of Historical Documents (Kyōtoshi Rekishi Shiryōkan), located by the imperial palace in Kamigyō Ward. The library has made available a collection of photographs of ancient documents, comprising around 210,000 separate frames in total, from the Kyoto municipal area. These were collected as part of editorial work that began in 1938, with the launch of the Institute for the Compilation of Historical Material on Kyoto (Kyōto Shishi Hensanjo). Its holdings compromise, moreover, some 90,000 historical documents, including the archive of the Restoration period courtier, Iwakura Tomomi (Iwakura Tomomi kankei shiryō), which is designated an important cultural property. There are some 50,000 books at the archive, too.

The historian Hayashiya Tatsusaburō played the leading role in collecting archival material on Kyoto city. ${ }^{21}$ His method was to set aside temple and shrine archives, and concentrate rather on the collection, copying and publication of historical records from city neighborhoods and surrounding villages. He reasoned that temples and shrines were insular by nature,

20 http://www.archives.kyoto.jp

21 On this endeavor, see Kobayashi 2014. 
and access to their documents would be difficult. Since the Meiji period, the Historiographical Institute at the University of Tokyo and the Graduate School of Letters at Kyoto University have been collating and classifying ancient and mediaeval temple and shrine documents relating to Kyoto. Meiji period historians were clearly biased towards these earlier periods. As a result, the vast early-modern and modern collections of shrine and temple documents have remained to this day largely uncatalogued. However, there now exists a finite number of historical studies that draw on those long-neglected sources. Among those sites whose modern history has been the subject of recent research are the Upper Kamo Shrine, the Fushimi Inari Shrine, Kiyomizu Temple, the Honganji Temple and the modern Heian Shrine. ${ }^{22}$ In addition, the temples of Daigoji, Tōji, Sennyūji, Honganji, Shōkokuji, and Kiyomizu each have permanent treasure houses of archival material for which they employ a curator. It is worth noting that these temples and shrines were encouraged to establish such archives within their precincts for the preservation of historical documents during the 1920s. The initiative came from the historian Kuroita Katsumi, who was inspired by the German Heimatschutz movement.

When it comes to published work on modern Kyoto, there is a growing body of material. A standard resource is Kyöto no rekishi published in ten volumes by Gakurin Shobō between 1973 and 1976. Based on exhaustive research conducted throughout the city, the clear, accessible text is aimed at Kyoto citizens. The coverage of modern and contemporary history in volume 7 on the Meiji Restoration (Ishin no gekidō), volume 8 on the modernization of the ancient capital (Koto no kindai), and volume 9 on Kyoto in world history (Sekai no Kyōto) is comprehensive. These volumes are an invaluable guide to understanding the basic historical facts, and the issues at stake in the study of Kyoto's modern history. The city subsequently

22 Ōyama, 2006; Fushimi Inari Taisha ed., 2011; Kiyomizudera 1997; Sennyūjishi 1984; Honganjishi 1969; and Heian Jingū 1997. 
published a sequel, Kyoto shiseishi in five volumes, covering the history of the municipal government. ${ }^{23}$ Other published collections include Shiryō: Kyōto no rekishi by Heibonsha in sixteen volumes (1979-1994), which comprises key documents from each ward of the city. This was in fact a by-product of the afore-mentioned Kyōto no rekishi series. Shinsen: Kyōto sōsho, published in twelve volumes by Rinsen Shoten (1984-1989), contains such modern historical sources as the afore-mentioned Keika yōshi and Miyako no sakigake.

The Kyoto Prefectural Library and Archives - forerunner of the Kyoto Institute - abandoned its attempt to compile a hundredyear narrative history of Kyoto Prefecture, but their endeavors nonetheless resulted in a valuable ten-volume prefectural chronology, styled Kyöto fu hyakunen no nenpyō (1970-1971). Volumes are devoted to such topics as modern governmental administration and commerce and industry. For each item in the chronology, the primary sources - administrative documents, private documents, and newspaper articles - are cited, making this an indispensable guide. The Kyoto Prefectural Library and Archives also published multi-volume collections of basic sources. These include the nine volume Kyōto fu hyakunen no shiryo (1972), a collection covering a century of Kyoto Prefecture, and the four volume Kyōto fu tōkei shiryōshü: hyakunen no tōkei (1969-1971), a compilation of statistics for the same period. These volumes constitute evidence of the energy and the editing skills of the staff at this pioneering archive. When it comes to the history of research on Kyoto, the archive's catalogue, styled Kyöto fu shiryō mokuroku (1983), classifies research papers and historical documents from the early-modern period to the current day. This is so vital a guide for pinning down historical Kyoto research, that it raises questions about the present-day reliance on digitalization and the internet. Otherwise, useful reference works relating to modern Kyoto include Kyöto shi no chimei (Heibonsha, 1979), Kyōto fu no chimei (Heibonsha, 1981), and Kadokawa Nihon chimei daijiten: Kyōto in two volumes (Kadokawa Shoten, 1982),

${ }^{23}$ Kyōto Shi Kyōto Shiseishi 2003. 
all of which relate to the history of place names. Meanwhile, the Kyōto rekishi atorasu, an historical atlas edited by Ashikaga Kenryō and published by Chūō Kōronsha in 1994, offers an excellent understanding of Kyoto spaces.

The great fires that blazed through Kyoto in 1864 in the wake of battles between troops of Chōshù domain on the one hand and the armies of the bakufu fighting alongside Satsuma and Aizu domains on the other caused the most significant destruction to the city since the Önin Wars of the fifteenth century. This conflagration and then the transfer of the emperor and his court to Tokyo in 1869 were decisive moments in Kyoto's decline. Numerous publications in recent years have retold the narrative of Kyoto's fall and subsequent rise. Kobayashi Takehiro in his Meiji ishin to Kyōto (Rinsen Shoten, 1998), sees the eleventh-centenary of the founding of Heian in 1895 as the point at which regional society, and most notably, the old courtier class and their families, finally rallied. And Takagi Hiroshi in his Kindai tennōsei no bunkashiteki kenkyū: tennō shünin girei, nenjū gyōji, bunkazai (Azekura Shobō, 1997) identifies the revitalization of the ancient capital of Kyoto in the 1880s, as a strategy for presenting traditional Japanese culture to international society. Meanwhile, Kindai Kyōto no kaizō toshi: keiei no kigen 1850 - 1918 nen (Minerva Shobō, 2006) is a useful collection of essays on the history of Kyoto city government, edited by Itō Yukio.

Various works examine the shift in the emperor system between the early modern and modern periods and its impact on Kyoto. Notable in this regard are the afore-mentioned history of the Sennyūji temple where the ancestral spirits of the imperial family were accommodated; Fujitani Takashi's Splendid Monarchy: Power and Pageantry in Modern Japan (University of California Press, 1996); a study of the Yase dojii by Uno Hideo (Yase dōji rekishi to bunka. Shibunkaku Shuppan, 2007); Itō Yukio's book on modern emperors and Kyoto (Kyōto no kindai to tennō. Chikura Shobō, 2010); Takagi Hiroshi's work on the modern emperor system and ancient capitals (Kindai tennōsei to koto. Iwanami Shoten, 2006), and John Breen's study of 
imperial ritual (Girei to kenryoku: tennō no Meiji Ishin (Heibonsha, 2011). Then there is a selection of more focused studies on Kyoto's modern transformation. There are books on Kyoto's three great infrastructure projects (Kyōtoshi sandai jigyoshi, Kyoto City Hall, 1912); on the history of electricity in Kyoto (Kyōto shiei denki jigyō enkakushi, Kyōto Denkikyoku, 1933); on civilization and enlightenment (Tanaka Ryokkō, Meiji bunka to Akashi Hiroakira ō, 1942); on the Lake Biwa Canal project (Biwako sosui no hyakunen, Kyōto Shinbunsha eds., Kyōtoshi Suidōkyoku, 1990); on the modern sewage system (Kyōtoshi gesuidōshi, Kyōto Shi Gesuidōkyoku eds., 2001), and on local development across the prefecture (Takaku Reinosuke's Kindai Nihon to chiiki shinkō: Kyōto fu no kindai, Shibunkaku Shuppan, 2011).

The history of education in Kyoto has received much attention in recent years. There is Tsuji Michiko's Tenshō no machi Kyōto: minshū no shakai to seikatsu (Aunsha, 1999), which discusses the pioneering establishment of primary schools in early Meiji. Elsewhere, many of the universities in Kyoto have published their own official hundred-year histories. These include Kyōto daigaku hyakunenshi (1997-present), Ritsumeikan hyakunenshi (1999-present), and Döshisha hyakunenshi (1979). In addition, there is Motoyama Yukihiko's edited volume, Kyōto fukai to kyōiku seisaku, (Nihon Tosho Sentā, 1990), a history of educational administration. Tanaka Tomoko's Kindai Nihon Kyōiku taisei no reimei: kōsaku suru chiiki to kuni to Kirisutokyōkai (Shibunkaku Shuppan, 2012) draws on primary sources to track the development of higher education up until the 1880s, for which Kyoto Prefecture - rather than the national government - was responsible. Finally, Matsuo Takayoshi's Takigawa jiken (Iwanami Shoten, 2005) is an indispensable work for reflecting on the tradition of democracy and university autonomy in Kyoto.

When it comes to the history of museums, Tokyo inevitably leads the way, but for the Kyoto National Museum there is now a hundred-year history, the Kyōto kokuritsu hakubutsukan hyakunenshi, published by Benridō in 1997. It makes use 
of the museum's own archives to construct an empirical account of the museum's development from the Meiji Restoration to the present day. The situation of fine arts in modern Kyoto is unlike that in Tokyo, where the Tokyo Bijutsu Gakko took the lead. In Kyoto, fine arts were closely related to crafts and the export industry, as in the case of Nishijin textiles and Kiyomizu ceramics. In addition, the Nihonga school of Japanese painting from the time of the Shijo faction and the Nanga school, as represented by Tomioka Tessai, forged their own unique path of development. There are important studies of the artists and their works of art. A representative inventory might begin with Tanaka Hisao's biography of Takeuchi Seihō, the leader of modern Kyoto's art scene (Takeuchi Seihō, Iwanami Shoten, 1988); Oka Yoshiko's study of the modern potter, Ninsei (Kokuhō Ninsei no nazo, Kadokawa Shoten, 2001); Tamamushi Satoko's study of the impact of Rinpa artists on Japonism in Europe and the US (Ikitsuzukeru Körin: imēji to gensetsu o hakobu norimono to sono kiseki, Yoshikawa Kōbunkan, 2004). Shimada Yasuhiro's study of modern Nihonga paintings (Kyōto no nihonga: kindai no yōran Kyōto Shinbunsha, 1991), and Namiki Seishi's introduction to traditional Kyoto crafts (Kyōto dentō kōgei no kindai, Shibunkaku Shuppan, 2012) are valuable. Inaga Shigemi's edited volume on traditional crafts, Dentō kōgei saikō: Kyō no uchisoto: Kako hakkutsu, genjō bunseki, shōrai tenbō (Shibunkaku Shuppan, 2007), has set a new benchmark.

When it comes to performing arts and entertainment in Kyoto, especially the activities and achievements of the postwar research group, there is a good deal on the Geinōshi Kenkyūkai established in 1963. Their magazine Geinöshi kenkyü frequently carries pieces on modern Kyoto, but especially useful for their adoption of a chronological approach are three volumes: Moriya Takeshi's Miyako no geinō: ōchō kara ishin made (Chūkō Shinsho, 1979); Okada Mariko's Kyōmai Inoue-ryū no tanjō (Shibunkaku Shuppan, 2013); and, of course, the Kyoto volume of the modern kabuki chronology published as Kindai kabuki nenpyō: Kyōto hen by Yagi Shoten (1995-2005). Kyoto folk customs and traditions feature in 
Tanaka Ryokkō's Ryokkō sōsho in fifty-four volumes published by Kyō o Kataru Kai from 1957 through 1972). Tanaka’s concern for urban customs is quite different from that of the great folklorist, Yanagita Kunio. Ema Tsutomu was lecturer at Kyoto's municipal art and crafts school and founder of the Kyoto folklore society, and his collected works are published as Ema Tsutomu chosakushü in twelve volumes by Chūō Kōronsha (1975-1978). The authoritative pre-war voice is Inoue Yorihisa's Kyōto koshüshi (Kanyū Shinshoku Kai, 1940). Otherwise, two works on the Gion Festival merit attention: Gion matsuri (Gion Matsuri Hensan Iinkai and Gion Matsuri Yamabako Rengōkai eds., Chikuma Shobō, 1976) and Yama, hoko, yatai no matsuri: furyū no kaika (Ueki Yukinobu, Hakusuisha, 2001).

Kyoto's modern architecture is dealt with by Nakagawa Osamu in his authoritative Kyōto modān kenchiku hakken (Tankōsha, 2002), and the same author's Kyōto to kindai: semegiau toshi kükan no rekishi (Kashima Shuppankai, 2015); there are also Kyō, machizukuri shi by Takahashi Yasuo and Nakagawa Osamu (Shōwadō, 2003), and Kinsei kindai machiya kenchiku shiron (Chūō Kōron Bijutsu Shuppan, 2004) by Ōba Osamu. Meanwhile, Amasaki Hiromasa and others examine Kyoto's modern landscape and scenery in Ueji no niwa: Ogawa Jihè no sekai (Tankōsha, 1990). For Kyoto's modern gardens more specifically, Kindai Nihon köenshi no kenkyü by Maruyama Hiroshi (Shibunkaku, 1994) and Higashiyama: Kyoto fükeiron by Katō Tetsuhiro, Nakagawa Osamu and Namiki Seishi (Shōwadō, 2006) are also valuable. Population studies of Kyoto that span the early modern and modern include Hamano Kiyoshi's Kinsei Kyōto no rekishi jinkögakuteki kenkyü: toshi chōnin no shakai kōzō o yomu (Keio University Press, 2007). Meanwhile, there is important work on the history of social movements in modern Kyoto. Essential are Watanabe Tōru on labor movements (Kyōto chihōo rōdō undōshi (Sangatsu Shobō, 1959), and two collections on the struggles of Kyoto's discriminated communities: Suihei undōshi no kenkyü, published in six volumes by the Buraku Mondai Kenkyūjo (1971-1973), and the ten 
volume Kyöto no burakushi published by the Kyōto Burakushi Kenkyūjo (1977-1995).

Finally, we might note the vital contribution made by university research centers in promoting research into modern Kyoto history. Kuromatsu Iwao of the Doshisha University Institute for the Study of Humanities and Social Sciences published a collection of essays on industry in the Nishijin quarter of the city as Nishijin kigyō no kenkyü (Minerva Shobō, 1965). The same research unit then published Senjika teikō no kenkyū: kirisutosha, jiyūshugisha no baai (Misuzu Shobō, 1968-1969), a series of reflections on resistance by Kyoto Christians and liberals during the war time. Ritsumeikan University's Institute of Humanities, Human and Social Sciences published seventeen volumes of local history as Kyöto chiiki kenkyü between 1986 and 2003. The greatest body of work has come from the Institute for Research in Humanities (Jinbun Kagaku Kenkyūsho), at Kyoto University. The pioneering historians, Hayashiya Tatsusaburō and Asukai Masamichi, were both based there, and their collaborative research was published respectively as Bunmei kaika no kenkyü (Iwanami Shoten, 1979) and Kokumin bunka no keisei (Chikuma Shobō, 1984). Both volumes explore Kyoto culture in the context of the Meiji Restoration. Takagi Hiroshi of the same institute has headed multiple projects that have resulted in multi-authored, interdisciplinary collections that argue for the universality and the particularity of Kyoto's modern history. With Maruyama Hiroshi and Iyori Tsutomu, he has edited Kindai Kyōto kenkyū and Miyako no kindai, both published by Shibunkaku in 2008 . Takagisubsequently edited a second collection exploring modern Kyoto's history alongside that of Nara, the other ancient capital (Kindai Nihon no rekishi toshi: koto to jōka machi, Shibunkaku Shuppan, 2013).

The present volume, Kyoto's Renaissance, draws on this wealth of work - edited primary sources, as well as critical writings in order to offer the reader a new empirically-based, historical exploration of the quintessentially modern "ancient capital" of Kyoto. 


\section{REFERENCES}

Berry 1997

Mary Elizabeth Berry. The Culture of Civil War in Kyoto. University of California Press, 1997.

Britton 1997

Dorothy Britton. "Richard Ponsonby-Fane: A Modern Scholarly William Adams." In Ian Nish ed., Britain and Japan: Biographical Portraits 2. Japan Library, 1997.

Dougill 2006

John Dougill. Kyoto: a cultural history. Oxford University Press, 2006.

Fiévé 2013

Nicolas Fiévé. "Social discrimination and architectural freedom in the pleasure district of Kyoto in early modern Japan." In Nicolas Fiévé and Paul Waley eds. Japanese Capitals in Historical Perspective, pp. 67-99.

Fiévé and Waley 2013

Nicolas Fiévé and Paul Waley eds. Japanese Capitals in Historical Perspective: Place, Power and Memory in Kyoto, Edo and Tokyo. Routledge, 2013.

Fushimi Inari Taisha 2011

Fushimi Inari Taisha ed. Fushimi inari taisha gochinza sensanbyakunenshi. Fushimi Inari Taisha, 2011.

Gay 2001

Suzanne Gay. The Moneylenders of Late Medieval Kyoto. Hawaii University Press, 2001.

Hareven 2002

Tamara K. Hareven. The Silk Weavers of Kyoto: family and work in a changing traditional industry. University of California Press, 2002.

Heian Jingū 1997

Heian Jingū shi hyakunen shi. Heian Jingū, 1997.

Honganjishi 1969

Honganjishi (3 vols.). Jōdo Shinshū Honganjiha Shūmusho, 1969

Jinkai Kenkyūkai 2010

Jinkai Kenkyūkai ed. Kitagaki Kunimichi nikki Jinkai. Shibunkaku Shuppan, 2010.

Kerr 2016

Alex Kerr with Kathy Arlyn Sokol. Another Kyoto. Sekai Bunka Publishing, 2016.

Kiyomizudera 1997

Kiyomizudera shi (2 vols.). Hōzōkan, 1997.

Kobayashi 2014

Kobayashi Takehiro. Kyōto ni okeru rekishigaku no tanjö: Nihonshi kenkyū no sōzōshatachi. Minerva Shobō, 2014.

Kyōto Shi Kyōto Shiseishi 2003

Kyōto Shi Kyōto Shiseishi ed., Kyōto shiseishi (vols.1-5). Kyōto Shi, 2003.

McKelway 2006

Matthew McKelway. Capitalscapes: Folding Screens and Political Imagination in Late Medieval Kyoto. Hawaii University Press, 2006. 
Mosher 1964

Gouverneur Mosher. Kyoto: a contemplative guide. Charles E. Tuttle Company, 1964.

Ōyama 2006

Ōyama Kyōhei ed. Kamigamo no mori, yashiro, matsuri. Shibunkaku Shuppan, 2006.

Pitelka and Tseng 2016

Morgan Pitelka and Alice Y. Tseng eds. Kyoto Visual Culture in the Early Edo and Meiji periods: The Arts of Reinvention. Routledge, 2016.

Plutschow 1992

Herbert Plutschow. Historical Kyoto. The Japan Times, 1992.

Ponsonby-Fane 1931

Richard Ponsonby-Fane. Kyoto: its History and Vicissitudes Since its Foundation in 792 to 1868. Rumford printing Press, 1931.

Sennyūjishi 1984

Sennyūji shi. Hōzōkan 1984.

Stavros 2015

Matthew Stavros. Kyoto: An Urban History of Japan's Premodern Capital. Hawaii University Press, 2015.

Yoshida 2002

Yoshida Morio. Nihon no koto wa naze küshū o manugareta ka. Asahi Shinbunsha, 2002. 